\title{
Oxidative stress induced by torsion of the spermatic cord in young rats ${ }^{1}$
}

\author{
Estresse oxidativo induzido por torção do cordão espermático em ratos jovens
}

\author{
Sergio Botelho Guimarães ${ }^{2}$, Alan Arruda Aragão ${ }^{3}$, Jefferson Menezes Viana Santos ${ }^{3}$, Osamu de Sandes Kimura ${ }^{3}$, Paulo \\ Hudson Uchoa Barbosa ${ }^{3}$, Paulo Roberto Leitão de Vasconcelos ${ }^{4}$ \\ 1. Research performed at Experimental Surgical Research Laboratory (LABCEX), Department of Surgery, Post-Graduation Program, \\ Federal University of Ceará (UFC), Brazil. \\ 2. MS, PhD, Associate Professor, Department of Surgery, Head of LABCEX, UFC, Brazil. \\ 3. Graduate student, UFC, Brazil. \\ 4. PhD, Associate Professor, Department of Surgery, Coordinator Post-Graduation Program in Surgery, UFC, Brazil.
}

\begin{abstract}
Purpose: To evaluate the effects of the oxidative stress in an experimental model of torsion/detorsion of the spermatic cord and the legitimacy of this model for oxidative stress studies. Methods: Forty-eight male Wistar rats were randomized in two groups ( $\mathrm{n}=24)$ : G-1 (Sham) and G-2 (Ischemia/Reperfusion). All rats received intraperitoneal saline injections ( $2.0 \mathrm{ml})$, at 21 , 9 , and $1 \mathrm{~h}$ before right spermatic cord torsion or first sham operation. Detorsion or second sham operation was carried out $3 \mathrm{~h}$ later followed by testis and blood samples collection (T-0). Additional samples were collected at 1-3-6 h time-points for assessment of testis malonaldehyde, glutathione, and plasma total antioxidant power (TAP). Results: Spermatic cord torsion/detorsion induced a significant increase in testicular malonaldehyde contents and a significant decrease in glutathione concentrations in ischemic rats compared with sham animals. Additional increase in malonaldehyde levels occurred during reperfusion in G-2 rats. TAP was similar in both groups denoting absence of systemic effects in this study. Conclusion: Torsion/detorsion of the spermatic cord for $3 \mathrm{~h}$ induces significant lipid peroxidation and reduction in glutathione content of the testis and is, therefore, a valid model for studying the oxidative stress effects of the ischemia/ reperfusion injury in young rat testis.
\end{abstract}

Key words: Antioxidants. Testis. Oxidative stress. Malonaldehyde. Glutathione. Rats.

\section{RESUMO}

Objetivo: Investigar os efeitos do estresse oxidativo utilizando um modelo experimental de torção/destorção do cordão espermático e a aplicabilidade do modelo para estudo do estresse oxidativo. Métodos: Foram utilizados 48 ratos distribuídos aleatoriamente em dois grupos (n=24): G-1 (Simulado) e G-2 (Isquemia/Reperfusão). Todos os animais receberam injeções intraperitoniais de solução salina $(2,0 \mathrm{ml})$ 21-9-1 horas antes da torção ou primeira operação simulada. A destorção/ segunda operação simulada (T-0) foi realizada após 3 horas, com coleta das amostras (testículo e sangue arterial) nesta ocasião e após 1-3-6 horas para determinação das concentrações de malonaldeído, glutationa e capacidade antioxidante total do plasma (CAT). Resultados: a torção do cordão espermático induziu aumento significante das concentrações de malonaldeído e redução simultânea das concentrações de glutationa nos ratos do grupo G-2, comparados ao grupo simulado. Ocorreu aumento adicional das concentrações de malonaldeído durante a reperfusão (G-2). A capacidade antioxidante total do plasma foi semelhante nos dois grupos estudados, denotando ausência de efeitos sistêmicos. Conclusão: A torção durante 3 horas seguida de destorção do cordão espermático induz um nível significante de peroxidação lipídica e redução da concentração de glutationa constituindo-se um modelo válido para o estudo dos efeitos do estresse oxidativo decorrente da lesão de isquemia/reperfusão no testículo de ratos jovens.

Descritores: Antioxidantes. Testículo. Estresse oxidativo. Malonaldeído. Glutationa. Ratos.

\section{Introduction}

Oxidative stress is a term denoting an imbalance between the production of oxidants and the respective defense systems of an organism. ${ }^{1}$ Oxidants encompass reactive oxygen species (ROS), reactive nitrogen species (RNS), sulfur-centered radicals and various others. Not all of these reactive species are radicals (molecules with one or more unpaired electrons). However, in many cases the reactive non-radical species will end up as radicals, damaging biomolecules by oxidation. This type of reaction may be self-sustained leading to extensive cellular damage. ${ }^{2}$ Testicular torsion is a serious urological emergency, usually involving newborns, children, and adolescents. The two most important factors determining testicular damage are the duration and degree of torsion of the spermatic cord. ${ }^{3,4}$ It has been demonstrated that reperfusion of the ischemic tissue promotes the generation of ROS, which arise from activation of the xanthine oxidase system in parenchymal cells or from leukocytes penetrating into interstitial tissue. ${ }^{5}$ Therefore the treatment by detorsion may further damage the testis. With 
the resumption of blood flow, oxygen needed for the conversion of hypoxanthine to uric acid is supplied to testis resulting in the production of large amounts of free radicals. These free radicals react with lipids in the cell and mitochondrial membranes, changing their permeability and disrupting cell integrity. ${ }^{6}$ Under normal conditions, free radicals are produced and their effects are counterbalanced by the endogenous antioxidant system. When ROS generation exceeds the defense mechanisms capacity to control, oxidative stress is generated and contributes to reversible or irreversible cell injury. As studies with experimental models of testis ischemia/reperfusion could bring new information for a better understanding of the local and distant repercussions of the oxidative stress induced by the torsion of the spermatic cord, this paper is aimed at evaluating these changes in the testis and the plasma of young rats and the validation of the animal model used here for oxidative stress studies.

\section{Methods}

Approval for experimental use of laboratory animals was obtained from the Commission of Ethics in Animal Research, Federal University of Ceará. Study groups consisted of 48 young Wistar male albino rats aged 55-65 days, 160-200g, provided by the Faculty of Medicine (Federal University of Ceará). The animals were housed in polypropylene cages at ambient temperature of $24^{\circ} \mathrm{C}$ on a $12 \mathrm{~h}$ light-dark cycle. Rats were allowed free access to food (Purina chow) and fasted $12 \mathrm{~h}$ before the experimental procedure. Tap water was offered $a d$ libitum until the beginning of the experiment. All rats received intraperitoneal saline injections $(2.0 \mathrm{ml})$ at 21,9 and $1 \mathrm{~h}$ before first sham operation or torsion of the right spermatic cord. All surgical procedures were performed under inhalatory ether anesthesia. Ischemia lasted $3 \mathrm{~h}$. Right testes were harvested and arterial blood samples were collected at the end of ischemia or second Sham operation $(0 \mathrm{~h})$ and 1,3 , and $6 \mathrm{~h}$ later and stored in deep-freeze for later analyses. Animals were randomly assigned to 2 equal groups $(n=24)$ :

Group 1 (two-sham operations control group): first shamoperation $\left(720^{\circ}\right.$ torsion followed by immediate detorsion of the spermatic cord) was carried out $1 \mathrm{~h}$ after last saline injection. Second sham-operation was performed $3 \mathrm{~h}$ later and consisted in simple exposure of the testis without further torsion/ detorsion, with immediate return of the gonad to the scrotum.

Group 2 ( $720^{\circ}$ torsion/detorsion group): torsion of the spermatic cord carried out $1 \mathrm{~h}$ after last saline injection. Detorsion was performed $3 \mathrm{~h}$ later.

\section{Chemicals and drugs}

Total Antioxidant Power kit (TA-01) was purchased from Oxford Biomedical Research (Oxford, MI, USA). All other chemicals were of analytical grade.

\section{Biochemical determinations}

Lipid peroxidation was assayed by measuring malondialdehyde as thiobarbituric acid (TBA) reactive substances. ${ }^{7}$ In brief, $\mathrm{H}_{3} \mathrm{PO}_{4}(1 \%, 3 \mathrm{ml})$ and aqueous TBA solution $(0.6 \%, 3 \mathrm{ml})$ were added to the $10 \%$ homogenate $(0.5$ $\mathrm{ml})$. The mixture was shaken and heated on a boiling-water bath for 45 min. After cooling, $n$-butanol was added and the mixture shaken. After separation of the butanol layer by centrifugation at $1200 \mathrm{~g}$ for $15 \mathrm{~min}$, its optical density was determined in a spectrophotometer (Beckman DU 640 B). The difference between the results of the two optical density determinations was taken as the TBA value and the amount of malondialdehyde (MDA) in the testis was calculated, comparing with MDA standards and expressed as $\mu \mathrm{Mol}$ MDA per gram of wet tissue. Glutathione (GSH) was assayed according to Sedlak and Lindsay's method published elsewhere. ${ }^{8}$ The amount of GSH was determined from a standard curve simultaneously obtained under the same conditions with standard solution of GSH. Total antioxidant power (TAP) of blood plasma was measured with the TA-01 kit from Oxford Biomedical Research (Oxford, MI). In this procedure, the $\mathrm{CU}^{+}$ derived from $\mathrm{Cu}^{++}$by the combined action of all antioxidants present in the sample is detected following complex formation between $\mathrm{Cu}+\mathrm{e}$ bathocuproine. The complex is stable and has an absorption maximum between 480-490 $\mathrm{nm}$. The absorbance values obtained from the samples are compared with a standard curve obtained using uric acid as a typical reductant.

\section{Statistical analysis}

Student's t-test was used to determine the level of significance between groups. Multiple comparisons were made using Tukey test. $\mathrm{P}<0.05$ was selected as the threshold of statistical significance.

\section{Results}

\section{Lipid peroxidation assay}

MDA concentrations were assayed in testis homogenates. There was a significant elevation in tissue concentrations of MDA in rats subjected to surgical trauma $(\mathrm{G}-1)$ in time-points T-1 $(\mathrm{p}<0.001)$ and T-3 $(\mathrm{p}<0.05)$ compared with T- 0 . Increase in MDA concentrations also occurred in G2 rats compared with sham-operated rats (G-1) in all time-points (Figure 1).

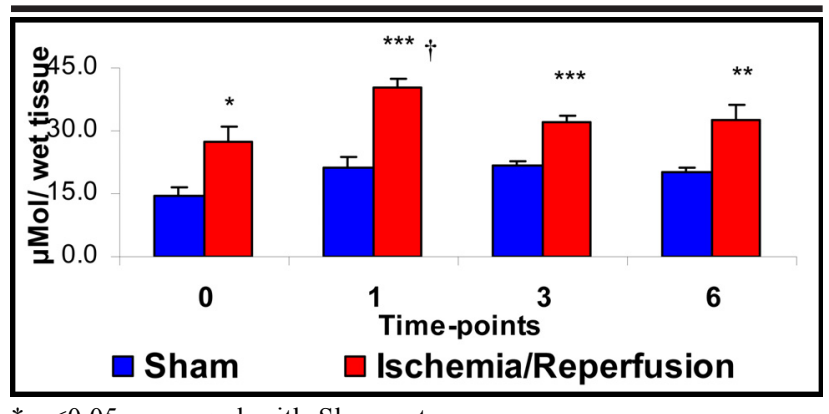

$* \mathrm{p}<0.05$ compared with Sham rats

** $\mathrm{p}<0.01$ compared with Sham rats

*** $\mathrm{p}<0.001$ compared with Sham rats

$\dagger \mathrm{p}<0.05$ compared with T-0 time-point, same group

FIGURE 1 - Effect of surgical trauma and ischemia/reperfusion on the right testicle. Tissue levels of MDA $(\mu \mathrm{mol} /$ $\mathrm{g}$ wet tissue) assayed at the end of second sham or ischemia and up to $6 \mathrm{~h}$ later in sham-operated rats (G-1) compared with rats submitted to ischemia (3 h) followed by reperfusion $(6 \mathrm{~h})(\mathrm{G}-2)$. 


\section{Reduced glutathione assay}

GSH levels were assayed in testis homogenates. GSH levels increased significantly during post-trauma in T-1 and T-3 time-points compared with T-0 in Sham-operated (G-1) rats. GSH levels decreased significantly in rats submitted to torsion/detorsion of the spermatic cord (G-2) compared with Sham-operated rats in all time-points (Figure 2).

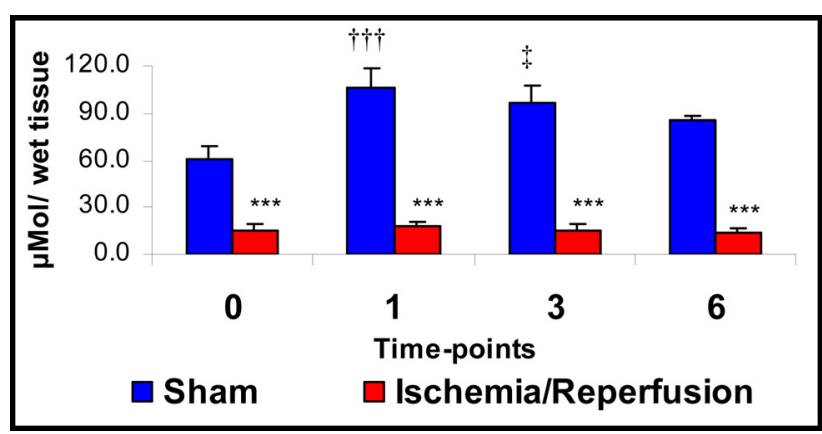

*** $\mathrm{p}<0.001$ compared with Sham rats

$\dagger \dagger \dagger \mathrm{p}<0.001$ compared with T-0 time-point, same group

$\ddagger \mathrm{p}<0.05$ compared with T-0 time-point, same group

FIGURE 2 - Effect of surgical trauma and ischemia/ reperfusion on the right testicle. Tissue levels of GSH ( $\mu \mathrm{mol} / \mathrm{g}$ wet tissue) assayed at the end of second sham or ischemia and up to 6 h later in sham-operated rats (G-1) compared with rats submitted to ischemia $(3 \mathrm{~h})$ followed by reperfusion $(6 \mathrm{~h})(\mathrm{G}-2)$.

\section{Total antioxidant power assay}

Total antioxidant power (TAP) was assayed in the blood plasma. Plasma levels of total antioxidant power were not different when comparing Sham-operated (G-1) with rats submitted to ischemia (G-2) (Figure 3).

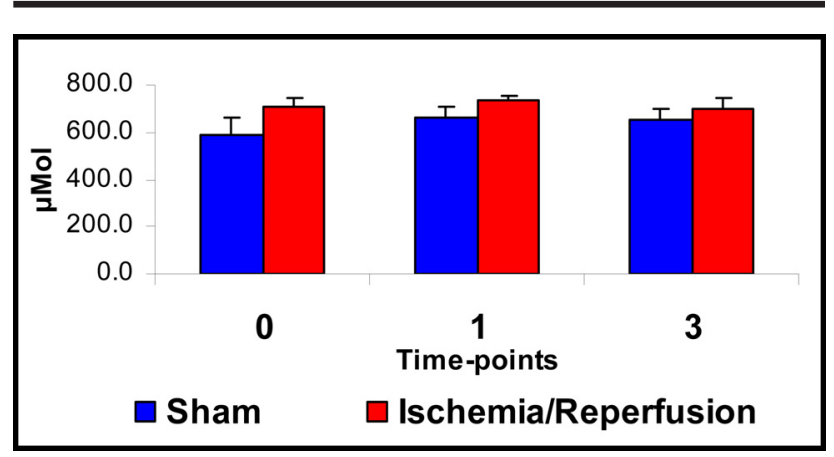

FIGURE 3 - Effect of surgical trauma and ischemia/reperfusion on the Plasma total antioxidant power (TAP) levels. TAP levels ( $\mu \mathrm{mol})$ assayed at the end of second sham or ischemia and up to $3 \mathrm{~h}$ later in sham-operated rats (G-1) compared with rats submitted to ischemia $(3 \mathrm{~h})$ followed by reperfusion $(3 \mathrm{~h})(\mathrm{G}-2)$.

\section{Discussion}

In most tissues, malonaldehyde (MDA), a thiobarbituric acid reactive substance (TBARS) is formed as a result of the peroxidative decomposition of polyunsaturated fatty acids. Therefore, measurements of amount of MDA provide an index of oxidative stress and lipid peroxidation. ${ }^{9}$ The significant increase of MDA levels at the end of the ischemia and during the reperfusion in rats submitted to the torsion of the spermatic cord show that 3 -h ischemia promotes severe cell membrane peroxidation (Figure 1). On the other hand, the additional increase of MDA levels $1 \mathrm{~h}$ and $3 \mathrm{~h}$ after detorsion of the spermatic cord reassures that additional injuries occur during reperfusion as has been reported previously by Akgur et al. ${ }^{10}$ Glutathione (GSH) is a tripeptide, L-g-glutamyl-L-cysteinyl-glycine, mol. wt. 307, is the major low-molecular-mass thiol compound in plants and animals ${ }^{11}$ and is an important cellular thiol "redox buffer" participating actively in the maintenance of the thiol/ disulfide redox potential. Glutathione disulfide (GSSG) is formed upon oxidation and is referred to as "oxidized glutathione". ${ }^{12}$ Compared to sham animals the concentration of GSH in G-2 rats decreased 4 to 6-fold. This significant $(p<0.001)$ decrease in GSH levels is an indicative of severe oxidative stress. Surgical trauma altered the concentrations of testis glutathione as observed in T-1 and T-3 time points (Figure 2). Increased glutathione levels in equal pace with increased levels of malonaldehyde (Figure 1) may indicate a protective cell response to the testis manipulation in two instances. Antioxidant status in biological samples is regarded as an indicator of oxidative stress. Low antioxidant capacity of tissue and body fluids is suggestive of increased oxidative processes. Assessment of the total antioxidant activity in biological samples may be carried out by different methods. These tests are designed to measure the sum of the contributions of all antioxidants present in a biological fluid. ${ }^{2}$ The total peroxyl radical-trapping potential (TRAP) method has been originally proposed by Wayner et al. ${ }^{13}$ It measures the time required to use up the antioxidants in a sample challenged with a constant flux of peroxyl radicals generated by adding either a lipophilic or a water soluble radical generator to the sample. The Trolox equivalent antioxidant capacity (TEAC) test measures the scavenging of the strongly absorbing radical cation $\mathrm{ABTS}^{+}\left(2,2^{\prime}\right.$ azinobis3-ethylbenzothiazoline 6-sulfonate), comparing the efficiency to trolox $\mathrm{C}$ as a reference. ${ }^{14}$ The ferric reducing ability of plasma (FRAP) uses the antioxidants in a sample to reduce ferric ion in a complex with tripyridiltriazine to a colored ferrous complex. ${ }^{15}$ Other methods for the assessment of oxidative status in vivo and ex vivo include the Oxygen radical absorbance capacity (ORAC) ${ }^{16}$ and the Cyclic voltammetry $(\mathrm{CV}) .{ }^{17}$ The Total antioxidant power kit (TA$01)$ used in this study is able to verify the global effects of different antioxidants including lipid soluble (vitamin E) and water-soluble antioxidants (uric acid, vitamin C, bilirrubin, thiols and gluthatione). The absence of significant differences in the total antioxidant power levels in the plasma of sham (G-1) and ischemic animals (G-2) suggests that the torsion of the spermatic cord does not affect the plasma antioxidant system, at least under the conditions of the present experiment (Figure 3). 


\section{Conclusion}

Torsion of the spermatic cord for $3 \mathrm{~h}$ followed by detorsion, used in this experiment, induces significant lipid peroxidation and reduction in glutathione content of the testis and is therefore a valid model for studying the oxidative stress effects of the ischemia/reperfusion injury in rats.

\section{References}

1. Abes, M, Sarýhan H, Deger O, Uydu HA. The effect of $\mathrm{ATPMgCl}$ on prevention of reperfusion injury after unilateral testicular torsion. Eur J Pediatr Surg. 2001;11(4):255-8.

2. Halliwell B, Gutteridge JMC. The definition and the measurement of antioxidants in biological systems. Free Rad Biol Med. 1995; 18(1):125-6.

3. Abuja PM, Albertini R. Methods for monitoring oxidative stress, lipid peroxidation and oxidation resistance of lipoproteins. Clin Chim Acta 2001; 306:1-17.

4. Výsser AJ, Heyns CF. Testicular function after torsion of the spermatic cord. BJU Int. 2003; 92(3): 200-3.

5. Granger DN, Korthuis RJ. Physiological mechanisms of postischemic tissue injury. Annu Rev Physiol. 1995;57:311-32.

6. Reilly, P.M.; Schiller, H.J.; Bulkley, G.B. Pharmacologic approach to tissue injury mediated by free radicals and other reactive oxygen metabolites. Am J Surg. 1991; 161(4):488-503.

7. Uchiyama, M.; Mihara, M. Determination of malondialdehyde precursor in tissues by thiobarbituric acid test. Anal Biochem. 1978; 86(1):271-278.
8. Sedlak J, Lindsay RH. Estimation of total, protein-bound, and nonprotein sulfhydryl groups in tissue with Ellman's reagent. Anal Biochem. 1968; 25:192-205.

9. Turan, C., Kucukaydin, N., Bekerecioglu, A., Kazez, A., Dogan, P., and Kucukaydin, M. (1996). The effect of vitamin $\mathrm{E}$ on ipsilateral and contralateral testis following unilateral testicular torsion in rats. Res Exp Med (Berl). 1996; 196(4): 243-6.

10. Akgür FM, Kilinç K, Aktug T, Olguner M. The effect of allopurinol pretreatment before detorting testicular torsion. J Urol. 1994;151(6): 1715-7.

11. Meister A, Anderson ME. Glutathione. Ann Rev Biochem. 1983; 52:711-60.

12. Sies H. Glutathione and its role in cellular functions. Free Rad Biol Med. 1999; 27(9/10): 916-21.

13. Wayner DD, Burton GW, Ingold KU, Locke S. Quantitative measurement of the total, peroxyl radicaltrapping antioxidant capability of human blood plasma by controlled peroxidation. The important contribution made by plasma proteins. FEBS Lett. 1985;187(1):33-7.

14. Miller NJ, Rice-Evans C, Davies MJ, Gopinathan V, Milner A. A novel method for measuring antioxidant capacity and its application to monitoring the antioxidant status in premature neonates. Clin Sci. 1993; 84(4):407-12.

15. Benzie IF, Strain JJ. The ferric reducing ability of plasma (FRAP) as a measure of "antioxidant power": the FRAP assay. Anal Biochem. 1996; 239(1): 70-6.

16. Cao G, Prior RL. Measurement of oxygen radical absorbance capacity in biological samples. Methods Enzymol. 1999;299:50-62.

17. Buettner GR. The pecking order of free radicals and antioxidants: lipid peroxidation, alpha-tocopherol, and ascorbate. Arch Biochem Biophys. 1993; 300(2): 535-43.

\section{Correspondence:}

Sergio Botelho Guimarães

Departamento de Cirurgia

Rua Prof. Costa Mendes, $1608 / 3^{\circ}$ andar

60430-140 - Fortaleza - Ceará - Brazil

Phone: (55 85)3366-8063

Fax:(55 85)3283-7851

e-mail: mcirur@.ufc.br
Conflict of interest: none

Financial source: none

Received: August 08, 2006

Review: September 16, 2006

Accepted: October 20, 2006

\section{How to cite this article:}

Guimarães SB, Aragão AA, Santos JMV, Kimura OS, Barbosa PHU, Vasconcelos PRL. Oxidative stress induced by torsion of the spermatic cord in young rats. Acta Cir Bras. [serial on the Internet] 2007 Jan-Feb;22(1). Available from URL: http://www.scielo.br/acb. 